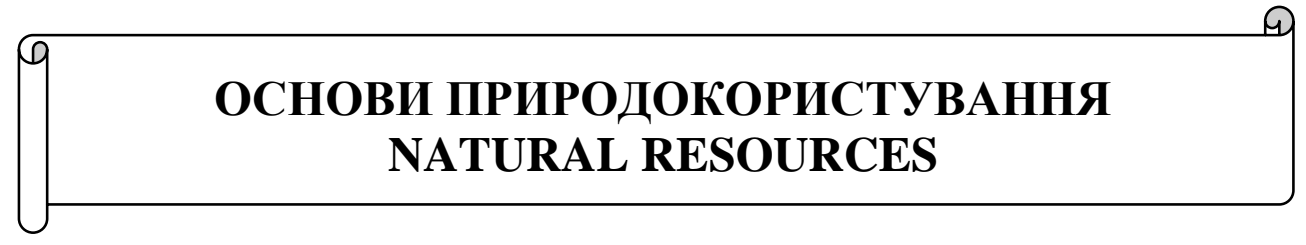

UOT 626.84

Bakhtiyar Mursal Mammadov, $\mathrm{PhD}$

e-mail: meliorasiya58@mail.ru

Institute of Soil Science and Agrochemistry of ANAS, Baku, Azerbaijan

\title{
EFFECT OF THE IRRIGATIVE WATER QUALITY ON ECOMELIORATIVE STATE OF SOILS
}

\begin{abstract}
Annotation. The article deals with the influence of the irrigative water quality on soil meliorative state and ecology. The higher qualitative water creates a healthy ecological environment by affecting the soil meliorative state. This article informs us about rivers, lakes, sea, slop and underground waters and about usage opportunities from such waters in agricultural plants irrigation.

The terms of the international and interstates standards must be fulfilled in irrigative water use. A quantity of the injurious substances should be at a permissible limit. The water used in trickling and subsoil irrigation must be clean and limpid, the sizes of the particles floating in irrigation by the water-sprinkler machines and installations must be fitting to the exit diameter of the spraying apparatus tip.

The very turbid water on the surface irrigation creates difficulties in growing works by affecting the agricultural plants development negatively. The organic and mineral content of water render an influence on organoleptic indicators. The permissible limit improves irrigative water quality.

The qualitative waters play an important role in humus quantity increase.

Key words: water-sprinkler; irrigative water; soil; quality; ecomeliorative; organic and mineral substance; organoleptic index
\end{abstract}

\section{Introduction}

The article is dedicated to the effect of the water quality which is used in irrigation of the agricultural plants on increase of the plant productivity, improvement of the environment and meliorative-ecological state of soils. The information about the waters of the river, lake, storehouse, underground and sea, sewer water sources and their state, at the same time the information about an accordance to the international and interstates standards of the water quality which is used in irrigation is given. From this point of view permissible limits of the useful and harmful mixture in the 
irrigative water content are given. At the same time a role of the irrigative water in increase of the humus quantity is spoken.

\section{Research object and method}

The water samples taken from the rivers, lakes, artesian and subartesian wells, seas, sewer water sources have been admitted as a research object in order to study a quality of the irrigative water and its influence on improvement of the soil meliorative-ecological state. The chemical content of the samples taken from the water sources, the mechanical mixtures quantity, turbidity degree and transparency has been fixed on the basis of the generally accepted methods. But the criteria of the water quality indices (para-meters) have been determined according to the international and interstates standards.

\section{Analysis and discussion}

The waters of the rivers and lakes, underground and local flow, industrial and economical-life sewer are concerned the water sources for irrigation. Last years the sea water is begun to be used in irrigation. The taken water must be useful for irrigation of the agricultural plants. The water quality depends on quantity of organic and inorganic substances, microorganisms. The clay non-dissolved in water, residues of silt, plant and animal organisms, the different salts dissolved in water, gases, organic and inorganic combinations are a reason for water turbidity, and this changes its color and taste. The water resource and expenditure in the water source must provide a need for it $[1,8]$.

To provide the tillage areas with the irrigative water, the waters on land surface (rivers, lakes, water canals) and underground are used. The atmospheric precipitations form a base of the water source. The atmospheric precipitations falling to the earth surface (snow, rain) are expended for the different places, and run into the rivers in a direction of the ground inclination and make ponds, springs, it is a reason for subsoil waters creation, but the rest part evaporates. So, the water constantly circulates in the nature.

The subsoil water quality is various depending on natural condition, but its content depends on their creating situation. A content of the atmospheric waters is filtered from surface into soil changes depending on salts and other substances in the land layers. The water gives one substance into soil, and gets the other one from it, but the soil keeps mechanical mixtures in itself. Therefore, the subsoil waters are mainly pure. To use from such waters can be considered very rational in irrigation with water-sprinkler, drops, aerosol, and subsurface. The soil keeps oxygen, and substances as ammoniac, phosphate acid and potassium salts which are necessary for plants development [3].

The open waters sources, i.e. the rivers, canals, water storehouse, lakes and ponds are used in irrigation [2].

The atmospheric waters form a basis of the river waters, partially subsoil waters. The river waters keep a lot of colloid substances from animal micro-organisms are found. From this reason the river waters are near the atmospheric waters according to their physical, biological and chemical characters. A quantity of the mechanical and organic mixtures in the river waters changes depending on the year seasons. The river waters' quality depends on geological structure and local condition of the zone. 
A number of various substances run into the rivers from the surface during the rainfalls and stream turbulent.

The salt quantity in the river waters can rise at the expense of the subsoil waters running into rivers. They are considered useful and necessary for watering of the agricultural plants. An observation of the dangerous microorganisms and bacteria in the river waters depends on presence of the dwelling points, communal and industrial enterprises. Fitness of such rivers for water provision is fixed by its bacteriological and biological content.

The lake and storehouse waters are not flowing waters. They get the water from atmospheric, river and subsoil water sources. Therefore a structure of the lake and storehouse waters is various. The subsoil waters flowing into the lake and water storehouses rise the water hardiness, changes a temperature. The polluted waters flowing from the rivers contaminate the lake and storehouse waters. If it is necessary to use from the lake, pond and storehouse waters, firstly the chemical, bacteriological and biological content of the water must be fixed, then its fitness over setting must be defined [7].

The following main demands for a quality of the irrigative water must be made: it must improve a mechanical, chemical, biological, temperature regime of soil and it must be useful for irrigation with the available technics. A quality of the irrigative water is characterized by the water temperature, a quantity and coarseness of the particles floating in the water, the number of the organic and mineral substances in it (a quantity of soluble salt and chemical substances). The organic and mineral substances soak into soil by the irrigative water and rise its fertility, it causes an increase of the agricultural plants productivity [6].

Depending on water source its temperature is various. A water temperature in the open water sources mainly depends on air temperature, water deepness and water motion rate. An average temperature is $0-3^{\circ} \mathrm{C}$ in the lakes, but a temperature changes by $1-14^{\circ} \mathrm{C}$ in the artesian, kahriz (underground|pipe) and spring waters. While a temperature of the soil and air is low, the irrigative water cools the plant and consequently the plant development delays. Therefore, the water temperature should be near $20^{\circ} \mathrm{C}$. If the water temperature is low under the natural condition, then it must be warmed as soon as possible. Using from the waters of which temperature isn't lower than $14-17^{\circ} \mathrm{C}$ for irrigation is advisible. In this case $6-20 \%$ is economized for the irrigative water expended on plant unit, but productivity can rise till 14-20\% [9].

The water turbidity is a quantity of the organic particles with gram in 1 litre of water and it has a great importance for the irrigation systems. The lake, pond, plain river waters and subsoil waters aren't turbidity. The little deponent particles with the nutrient enter the area by the river waters which are considered a main water source, they moisten not only the soil but also fertilizer the area. The coarse particles in the silty waters which are transported by the canal, chute and pipeline trouble the deposit, and the little particles run into the area [9]. There mustn't be floating particles more than $0,5 \mathrm{~mm}$ in the water during the irrigation with the water-sprinkler machines as "Cuban", "Dnepr", "Freqat", "Voljanka" and others, the turbidity must be less than 1-1,5 g|l in irrigation with a hose, less than 3-4 g|1 in irrigation from underground pipelines [3].There mustn't be particles floating in the water during subsurface, dropping and aerosol irrigations, the water must be mechanically pure. That is, using of the silty water with these methods in irrigation isn't absolutely advisable. While performing irrigation with the surface method, stripe or furrows, the harmful 
mechanical mixtures in the more turbidity waters, especially the insoluble particles form a layer within the certain density. Then this stratum crusts, and consequently it hampers cultivation. Sometimes, the shoots are covered with the complete or partly these particles, this prevents the following development of the plants.

While performing water-sprinkler with the siltier water, the silty water splashe din a rain form falls on the plant trunk and leaves, disturbs photosynthesis processes, sometimes the plants bend as a result of heaviness and lose stableness. After irrigation the silty stratum remained on the leaves delays its development, and it may negatively effect on crop (especially fruit) appearance. A quantity of mineral substances in irrigation water for some plants is till 1-1,5 g|l, but saltness is till 5-8 g|l and it isn't considered dangerous. 15-20 g|l of the soluble salts quantity in water is considered harmful [2]. Therefore getting the water from the delta part of which mineralization decreased as a result of flowing sweet river water into the sea is advisable while using from the sea water in irrigation.

While using from slops in irrigation the chemical analysis must be performed in order to fix a quantity of the useful (phosphorus, nitrogen, potassium) and harmful (pitch, soda, phenol, oil products, lead, phtor and etc) substances and their number must be compared with the permissible concentration. During the comparison presence of more soda quantity is very dangerous $[1,6]$.

Using of the mineralized water in irrigation depends on mutual relation of some factors, for.ex. climate, zone draining, mechanical and chemical content of soilground, irrigation technics, plant agrotechnics.

A quality of natural water sources is characterized with a quantity of organic and inorganic substances, microorganisms, physico-chemical indices and pathogenic bacteria content. The water normal qualitative parameters and its differences from the permissible limit are determined by a standard. The farming-drinkable water equipment sources of State Standard 2761-84, "Centralized economical-drinkable water provision sources are chosen according to the standard hygienic, technical requirements and distinguishable rules" $[4,5]$.

The sanitary quality of water is regulated with the "Drinkable water" standard of State Standard 2874-82. The organoleptic indices as a taste, smell, transparence of water good for the human's organism in this standard, the harm-lessness and epidemic safety parameters of the water chemical composition were given. The water turbidity depends on particles quantity. The particles floating in the water form an important condition for pathogenic bacteria development. Therefore a content of the water which is floated by the pipelines is very seriously limited. Its concentration mustn't overstep 1,5 mg|l limit [4]. There is melted iron and humus substances in the pure water, and it is not dreadful for the organism. These substances give brownyellowish or yellow color to the water. When hudrosulphite (sulphur hudrogen) is present, its colour becomes greenish. The analyses show that presence of mineral substances in the water doesn't negatively influence on alive organisms. But mineral substances deteriorate the water taste, disturb transparence. Presence of the taste and smell in the pools, storehouses and lake waters is connected with the development, destruction, decomposing of the organic substances in the water and etc.

The mineral mixtures influencing on organoleptic composition of water musn't overstep the displayed limit, by $\mathrm{mg} \mid \mathrm{l}$ : dry residue -1000 , chloride $(\mathrm{Cl})-350$, sulphate $\left(\mathrm{SO}^{2-}\right)-500$, the iron $\left(\mathrm{Fe}^{2+} ; \mathrm{Fe}^{3+}\right)-0,3$, manganese $\left(\mathrm{Mn}^{2+}\right)-5,0$, aluminium $\left(\mathrm{Al}^{3+}\right)-$ 0,5 , metaphosphate $\left(\mathrm{PO}_{3}\right)-3,5$, zinc $\left(\mathrm{Zn}^{2+}\right)-5,0$, copper $\left(\mathrm{Cu}^{2+}\right)-1,0[8]$. 
Less mineralization of water (till $100 \mathrm{mg} /$ ) deteriorates its taste, but absence of salt (distilled water) in water is harmful for the human's organism. According to the information of the sanitary epidemiological service organs while dry residue quantity in water is till $1500 \mathrm{mg} \mid \mathrm{l}$, a quantity of iron in the used subsoil waters is till $1 \mathrm{mg} \mid \mathrm{l}$, it is considered admissible.

Chloride and sulfate concern the main quality indices of the water. While the concentration is high it can harmfully influence on plants. The approximate parameters by $\mathrm{mg} \mid \mathrm{l}$ which characterize the irrigative water fitness (fitness criterion for irrigation according to the chemical content of water) is as the following: while a quantity of oxygen in water content is more than 5 , salts are less than 800 , chlorides are less than 300, sulphates are less than 25, the same water is good for irrigation; but the water is considered useless for irrigation while oxygen is less than 3 , salts are more than 1200, chlorides are more than 400, sulphates are more than 300 [3, 8]. Presence of free chlorine, sulphur (more than $0,5 \mathrm{mg} \mid \mathrm{l}$ ) and fluorine (more than $1 \mathrm{~g} \mid$ ) in water is not permissible. The admissible maximal limit of the harmful substances must be so: mercury - 0,005 mg|l, arsen and selen - 0,05 mg|l, copper, cadmium, chrom, tin, cyanide, hydro-carbon, oil-products $-0,1 \mathrm{mg} \mid 1$, sulphide, trinitrobenzol - 0,5 mg|l, carbon-sulphide, fluorine (colourless gas) - 1mg|l, zinc $-5 \mathrm{mg} \mid \mathrm{l}$. The water quality mustn't lag behind drinkable water for the animal watering. At the same time, the requirements for its content, taste, smell, transparency can be reduced [7].

Improving the water qualities to dilute, to filter, to free from microbes, to purify the substances which inflict harm upon the human's and animals life and plants, and to lay obstacles for its using in industry, to improve an ecological state of soils and environment and to get pure product ecologically.

\section{Conclusion and recommendations}

1. The water must meet the following requirements, irrigation: the mexanical, chemical, biological, temperature, there should be suitable for irrigation equipment to improve their land. The quality of water for Irrigation water temperature, mineral and organic substances should be characterized by a number of parts floating in the water, its content and size. Chloride and sulphate salts are more than -1200 mql least partially, at least, are suitable for irrigation water, oxygen in water content is more than 5, salts are less than 800 , chlorides are less than 300, sulphates are less than 25 , the same water is good for irrigation; but the water is considered useless for irrigation while oxygen is less than 3 , salts are more than 1200, chlorides are more than 400 , sulphates are more than 300 .

2. Drip irrigation water in irrigation canals, rivers, reservoirs, lakes and ponds is efficient use of water sources, that is, the surface or underground water, and spray with sprinkler, sulsurface mainly by the method of mechanical cut off with jets open.

3. The natural water sources of organic and inorganic substances and microorganisms, bacteria causing the disease and physico-chemical indicators of the quality of content must be characterized with the composition of. Water quality and its allowable limit should be determined by the standards of nominal.

4. To improve water quality, free from germs, which can serve improvement of environmental situation is necessary to limit the damage to crops from a mixture of soil and environment in general. 


\section{REFERENCES}

1. Alasgarov, H.M. (2008). Agricultural water supply. Study guide. Ganja.

2. Andreev, N., et al. (1979). Cultural pasture on irrigated lands. Moscow: Kolos.

3. Bagirov, Sh.N. (1985). Melioration of Irrigation. Baku: Maarif.

4. Drinking water. ГОСТ 2874-73. Moscow: Goskomstandart.

5. Drinking water. Methods for determination of the mass concentration of fluoride. ГОСТ 4386-81. Moscow: Goskomstandart.

6. Isaev, I.P., Sergeev, B.I., \& Didur, V.A. (1990). Hydraulics and hydromechanization agricultural processes. Moscow: Agropromizdat.

7. Kazimov, T.M. (2009). In the livestock farm mechanization of water supply. Baku: Azerneshr.

8. Mammadov, B.M. (2011). Effect of environmental protection yields and quality of Irrigation water. Soil and agrohemistry, 20(1), 275-278.

9. Palishkin, N.A. (1990). Hydraulics in agricultural water supply. Moscow: Agropromizdat.

The article was received 31.10.2019 and was accepted after revision 10.01.2020

\section{Б.М. Мамедов \\ ВПЛИВ ЯКОСТІ ЗРОШУВАЛЬНОЇ ВОДИ НА ЕКОМЕЛІОРАТИВНИЙ СТАН ГРУНТІВ}

Анотація. У статті описано вплив якості зрошувальної води на екологічний та меліоративний стан грунту. Покращена якісна вода створює екомеліоративне середовище, яке впливає на екологічний та меліоративний стан грунту. Надано інформацію про склад річкових, озерних, морських, стічних і підземних вод, про їх використання при зрошенні сільськогосподарських культур. При використанні зрошувальної води слід дотримуватися міжнародних і міждержавних стандартів. Використовуючи при поливі воду зі шкідливими домішками, необхідно дотримуватися допустимих норм. При крапельному і підгрунтовому зрошенні поливна вода повинна бути чистою, під час дощування плаваючі частинки мають відповідати діаметру наконечника дощувального апарату. При поверхневому поливі занадто каламутна зрошувальна вода затримує розвиток рослин і створює труднощі під час обробки грунту.

Мінеральний і органічний склад води впливає на органолептичний показник. При допустимих концентраціях домішок поліпшується якість зрошувальної води. Зрошувальна вода відіграє важливу роль для підвищення кількості гумусу в грунті.

Ключові слова: дощування; зрошувальна вода; грунт; якість; екомеліоратив; мінеральні та органічні речовини; органолептичний показник

\section{Мамедов Бахтіяр Мурсал огли}

кандидат технічних наук, Інститут грунтознавства та агрохімії Національної академії наук Азербайджану

Адреса робоча: AZ1073 Азербайджан, м. Баку, вул. М. Рагіма, 5

e-mail: meliorasiya58@mail.ru 